UDC 621.311.4-519

\title{
DEVELOPMENT AND RESEARCH OF WI-FI NETWORK FOR RECEIVING AND TRANSMITTING TELEMECHANICAL INFORMATION IN THE TRAINING LABORATORY
}

\author{
Bogdan Orobchuk; Vadym Koval
}

\section{Ternopil Ivan Puluj National Technical University, Ternopil, Ukraine}

\begin{abstract}
Summary. The article deals with the issues of research, development and implementation of local area wireless networks in the educational process, especially with the study of the signal level for data transmission control of the local wireless network indoors. The controlled telemechanics unit uses wired systems for communication of the operator with various sensors and actuators, which creates certain difficulties and risks for the operator working in site of the telemechanics unit. The article considers a potential use of wireless technologies in the educational process, which demonstrates how to secure the operator and reduce the time to bypass all the sensors of the actuators, as well as to develop a short-range wireless subsystem.
\end{abstract}

Key words: telecommunication technologies, Wi-Fi, local area wireless network, educational process, telemechanics, electric power industry.

Statement of the problem. Nowadays, the system of higher technical education has to meet notably high demands: future professionals are to be prepared for competition and work in the dynamic environment which tends to continuously change and where the specialist often faces untypical tasks, solving of which needs skills and habits of developing and analyzing of both their own actions and the pace of different technological processes. The leading part in such system belongs to the modern method of preparing the educational process in the system of higher education in order to train the innovatively thinking specialists, as further they are going to be directly involved into formation and implementation of innovative policy in their professional activity $[1,2]$.

Analysis of the available investigations. In modern technological world, propagation and application of wireless information telecommunication technologies is a real and accomplished fact, especially in the educational process [3, 4]. Given research has been concentrated on analysis and evaluation of those technologies which use the frequency ranges from 2400 to $2483.5 \mathrm{MHz}$ and from 5725 to $5875 \mathrm{MHz}$, and also allocated frequencies that are used for scientific, medical, and industrial purposes as well as for operation of high-frequency units. These frequency ranges belong to ISM-range (Industrial, Scientific, Medical) [5]. Currently, Ukraine is given the permission «to build local area radio networks in the frequency band of 2400-2483.5 MHz based on the equipment with maximum transmitter power not more than $100 \mathrm{~mW}$ and maximum aerial gain factor $3.5 \mathrm{~dB}$ only within buildings, constructions, closed industrial and storage sites» [6].

The mentioned law [6] opens broad possibilities to legally implement similar networks in educational and scientific institutions of Ukraine, which, in turn, will make it possible to improve the quality of educational process and carry out the broad range of research with 
practical implementation of the own developed wireless technologies. It should be noted that studying of mutual influence of wireless equipment for the local and intranets development that function in the same frequency ranges but are used for digital and informational exchange of different standards (e.g., for frequencies $2.4 \mathrm{GHz}$ the standards are $802.11 \mathrm{~b} / \mathrm{g} / \mathrm{n}-\mathrm{Wi}-\mathrm{Fi}$, 802.15.4 - ZigBee, 6LoWPAN, 802.15.1 - Bluetooth, and for the frequencies $5 \mathrm{GHz}$ the standards are $802.11 \mathrm{a} / \mathrm{n}-\mathrm{Wi}-\mathrm{Fi}$ ) is the area of particular practical interest for implementation of small wireless telecommunication networks in higher educational and other scientific institutions [7].

Objectives of the research. Introducing of the wireless local networks and intranets in the educational institutions ensures quick access to information and high-tech equipment used in educational process for the tutors, students, and service staff and this way increasing the level of acquiring knowledge. Therefore, the aim of this research is to develop the wireless local network and study the ways of improving the quality of telemechanics control unit maintenance by means of hardware and software development which may solve the automation and safety problems. The object of the study is the developed training control simulator for power facilities operation, and the subject of research is the process of collecting and transmitting information from the control point of telemechanics $[8,9]$.

Statement of the task. Modern controllers of telemechanics systems are able to obtain information not only from sensors and transducers, but also from various microprocessor devices, such as metering devices, current protectors, microprocessor relay protection devices, and others. Some local interfaces, such as RS-485, are used to connect to such devices. The information exchange is carried out using one of the compatible standard protocols, for example, Modbus. The control unit (CU) of telemechanics in real systems is connected to the dispatching point (DP) remotely, usually at a large distance [10]. Therefore, a separate device must be used at the workplace for the operator who works directly on the site in the danger zone near the control cabinet. There is a necessity to make the work of service personnel safe. The simplest way is to take the control and information collection units of telemechanics CU out of the danger zone. For solving this problem the wireless technology can be used, which ensures the user-friendliness and eliminates the need to install cables [11].

The use of a large number of equipment operating in the same frequency range can cause problems with noise immunity and influence the information reliability of the network. Most modern radio systems transmit signals in the narrowband range and are quite sensitive to radio interference. For this reason, in order to protect from external interference, the techniques that allow to expand the signal spectrum are used in modern communication channels [12]. Our task was to investigate the negative impact of various wireless devices on the telemechanics equipment of the training simulator within the access of the built Wi-Fi network in the laboratory of power facilities remote control and its magnitude. To study the mutual influence of network equipment and for its evaluation, experimental tests of the constructed wireless Wi-Fi network for the training simulator of the automated control system of electric power facilities were carried out on the basis of Electrical Engineering Department of Ivan Puluj TNTU [13].

Structure of the developed wireless local area network. The simulator model of the automated control system, for which a wireless local area network is being developed, includes models of power substation transformers, switching devices, load models on outgoing lines, electric measuring equipment, sensors and telemechanical equipment. The model of the electric substation simulator makes it possible to study the methods of operational dispatch control, methods of remote control and telecontrol of electric networks and power consumption parameters practically. 
Currently, in the simulator model of the automated control system, communication between the controlled and control points is carried out using a two-wire communication line (RS-485 interface) to the serial port of the computer via the RS-232 interface. The training simulator is constructed on the equipment of the company «Strila» design bureau [14].

To ensure the reliability of data transmission, redundancy and duplication of the communication channel, which is currently a mandatory requirement for telemechanics systems in the power industry, the wireless local network was developed as an alternative communication channel for the training simulator model. The developed project uses software and hardware implementation based on two devices: receiver and transmitter (Fig. 1).

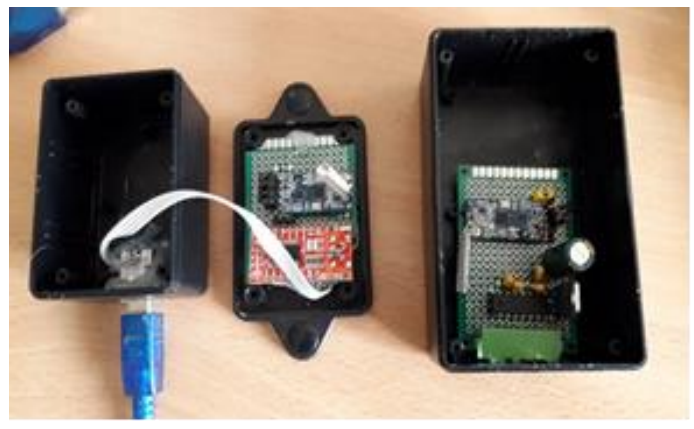

a) b)

Figure 1. Software and hardware implementation of a wireless network: a) transmitter, b) receiver

As a hardware component in the transmitter, two devices combined into one are used: a microcontroller for data collection via an analog-to-digital converter and a wireless transmission device.

The receiver uses only a wireless device to connect to the control cabinet. A six-channel analog-to-digital converter of the microcontroller, activated by means of connected libraries, is used as a software component that performs primary processing of information (which is transmitted or received).

A USB port is used to connect one wireless communication device to a personal computer (Fig. 2), and direct connection is used to connect another device to the control cabinet microcontroller (Fig. 3). In both cases, the UART / TTL standard works.

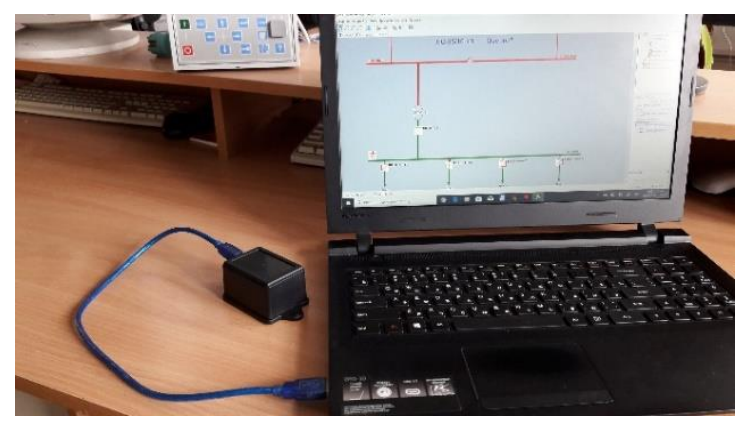

Figure 2. Connection of the transmitter to a $\mathrm{PC}$ via USB

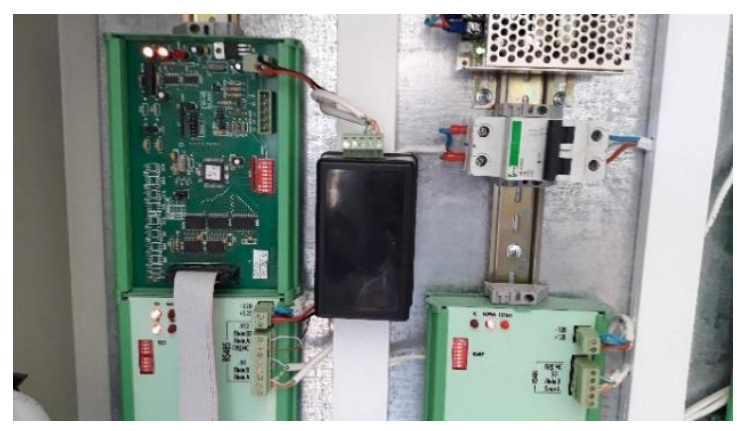

Figure 3. Connection of the receiver in the control cabinet via the RS-485 interface

The training software and hardware complex, on which the wireless local area network is implemented, has a three-level structure, as shown in Fig. 4.

Thus, it is necessary to organize the use of wireless communication for modeling more comfortable and safe working conditions on a training simulator. The purpose of this project is to improve the quality of the controlled telemechanics unit service by developing software and hardware, which solves the problem of automation and safety. A short-range wireless communication subsystem has been developed for the telemechanics control unit [15]. 


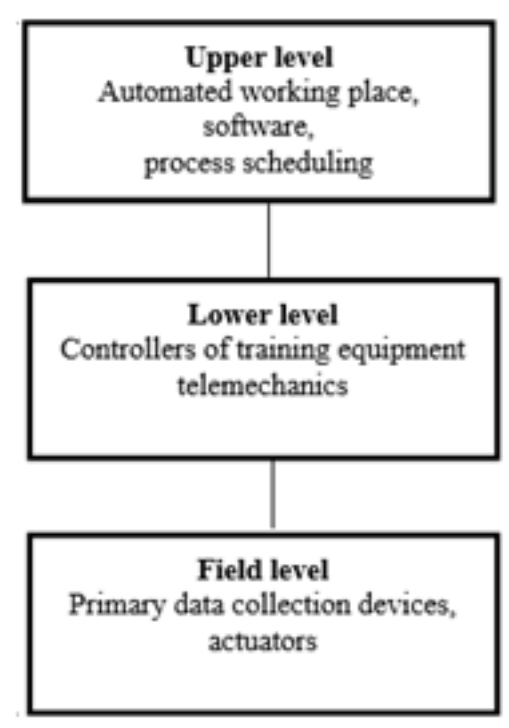

Figure 4. Three-level hierarchical structure of software and hardware complex

The developed software and hardware takes the information collection units of the telemechanics CU outside the dangerous working area, which includes the service personnel located at the site. The developed subsystem provides information transfer by means of wireless technology from the CU of telemechanics to SCADAsystem of a control point which can be located at distance from 100 to $1000 \mathrm{~m}$ from the CU.

The basis of the developed system is a programmable controller. The basis of the developed system is a programmable controller. Since it is necessary to perform analog-to-digital conversion within the developed Wi-Fi network, a microcontroller is used for this purpose, as almost all microcontrollers have analog-to-digital conversion.

In this project, we drew attention to the widespread family of 8-bit microcontrollers from Atmel, in particular, ATmega328 was chosen. The 10-bit analog-to-digital converter, which is part of this microcontroller, operates at a voltage of $0 \ldots 5 \mathrm{~V}$. The crystal is quite simple to program, has low power consumption, low cost, small size and high failure resistance. ATMega 328 contains $32 \mathrm{kB}$ of internal flash memory, which is sufficient for solving many tasks. The microcontroller also has a fairly high RAM volume $(2 \mathrm{kB})$. The performance is up to 20 million operations per second (MIPS).

The device APC220 from APPCON Technologies was chosen for wireless information transmission during the project implementation. This transmitter has sufficient external interference protection and communication range, taking into account low power consumption, low price and small dimensions. Its significant advantage is the accessible UART interface available, which allows easily connect to both the microcontroller and the personal computer. The data transfer rate is $19 \mathrm{kB} / \mathrm{s}$, which is sufficient to solve the training problems of modeling technological processes in the power industry. The declared power of transmitter is within $13 \mathrm{~dB}$, and the sensitivity of the receiver is $113 \mathrm{~dB}$

With all the above characteristics, the devices can communicate with each other at a distance of up to $1 \mathrm{~km}$. It should be noted that for this distance the data is transmitted at an operating frequency of $418 \ldots 455 \mathrm{MHz}$. Compared to other devices operating at $2.4 \mathrm{GHz}$, it is more appropriate to use the chosen device with a lower frequency, as the smaller sizes and lower power consumption are needed.

Considering the mentioned above, particular software Arduino IDE development environment complete with a circuit board platform, which meets the requirements of our project, was selected.

Thus, the use of all the described devices gave the possibility to achieve the aims and to arrange a short-range wireless communication subsystem for the training simulator of the automated control system.

Studying of interferences to the work of the developed network.

1. The influence of neighboring networks. Interference to the developed experimental network may result from neighboring Wi-Fi networks operating in the same frequency range. These interferences (also called intra-channel ones) occur in networks that belong to 
Development and research of Wi-Fi network for receiving and transmitting telemechanical information in the training laboratory

the $802.11 \mathrm{~b}$ and $802.11 \mathrm{~g}$ standards. In the $2.4 \mathrm{GHz}$ frequency band, there are only three non-overlapping channels (1, 6 and 11), although sometimes these channels need to be reused [16].

To study the effect of intra-channel interference in the experiment on the 1st channel, two D-link access points were set up. Then the speed of information transfer from the control point equipment to the controlled point equipment was tested. Consequently, other access points were switched on and off and the distance between them was changed $-10 \mathrm{~m}, 20 \mathrm{~m}$ and $30 \mathrm{~m}$. When the next access point at a distance of $10 \mathrm{~m}$ from the first was switched on, decrease in data rate averaged $50 \%$, at a distance of $20 \mathrm{~m}$ it was about $40 \%$, and at a distance of $30 \mathrm{~m}$ it was $25 \%$.

However, due to interference, in internal channels interference may occur between Wi-Fi devices operating on adjacent frequency channels. For example, the 1st frequency channel with a band from 2.401 to $2.423 \mathrm{GHz}$ and the 2 nd channel with a band from 2.406 to $2.428 \mathrm{GHz}$ were studued. The obtained results showed that the common area of the two adjacent channels is approximately $78 \%$ of the total width, which, in turn, causes a significant reduction in data rate and, accordingly, WLAN bandwidth.

Studies have shown that the information transmission speed by the communication channel to one of the $\mathrm{CU}$ is reduced during the operation of the second $\mathrm{CU}$ in the adjacent channel and is up to about $40 \%$, compared with the switched off one. In the study of the case when the involved access points operated on different frequency channels, the speed decreased by an average of $10 \%$. The obtained results show that the broadband propagation of radio waves in different frequency channels may also cause interference phenomena that can generate interference in all channels.

2. Impact of Bluetooth devices. During this experiment, it was investigated how the operation of Bluetooth devices in the $2.4 \mathrm{GHz}$ frequency range affects the data transfer rate of telemetry and telecontrol between the CU and DP in the developed Wi-Fi networks. To arrange access to communication channels, the 802.15.1 (Bluetooth) standard uses the method of spectral expansion based on Frequency Hopping Spread Spectrum (FHSS) [17]. It follows that the devices actually exchange information on 79 subchannels with a total width of $1 \mathrm{MHz}$ in the frequency range of $2.4 \mathrm{GHz}$ when they are switched approximately 1600 times per second. The use of FHSS-technology allows increasing the operation stability, respectively, this makes it possible to reduce the probability of using these frequency subchannels by other equipment at a certain time.

To estimate the impact of Bluetooth devices on the band rate of the $802.11 \mathrm{~g} \mathrm{Wi}-\mathrm{Fi}$ access point, which operates in the $2.4 \mathrm{GHz}$ frequency band, an experiment was made. The model of CU was installed at distance $10 \mathrm{~m}$ from the DP of the training simulator with the developed transmission device, and working devices with Bluetooth modules were placed between them. When determining the speed on the channels that were tested, a decrease in the speed of information exchange was detected within $20 \%$.

3. Influence of wireless radio devices. Modern radiotelephones are also potential sources of technical interference during the operation of the developed local wireless Wi-Fi network. In this experiment, we used an analog radio phone from Nokia with an operating frequency of $2.413 \mathrm{GHz}$, which corresponds to the range of the first frequency channel of the $802.11 \mathrm{~b} / \mathrm{g}$ standard. The test results showed that during a telephone conversation there is a break in the wireless connection between the CU and the DP on the 1st frequency channel, but the operation of the radiotelephone does not impact the operation of the developed local Wi-Fi network on channels 6 and 11. Several tests were also performed, during which the phone was removed from the process equipment at a distance of $10 \mathrm{~m}, 30 \mathrm{~m}$ and $50 \mathrm{~m}$, respectively. In the case when the phone was placed $10 \mathrm{~m}$ from the $\mathrm{CU}$, the speed of information exchange on the $1 \mathrm{st}$ 
channel decreased by $98 \%$, and at the distance $30 \mathrm{~m}$ and $50 \mathrm{~m}$, and the decrease of the speed of information exchange was 25 and 5\%, respectively.

An experiment was also conducted to study the effect of Samsung digital radiotelephone with a similar operating frequency of $2.4 \mathrm{GHz}$ and FHSS technology. The experiment showed that the work phone placed next to the developed Wi-Fi network at a distance of up to $20 \mathrm{~m}$ can reduce the speed of information exchange by maximum $15 \%$.

Conclusions. As a result of the performed development, the possibility of implementation and use of a wireless short communication channel for the telemechanics controlled point of the training simulator of the automated control system was considered.

During the implementation of this project the following tasks were solved:

- the technical means on which the set task was solved are chosen. The devices are compatible both with each other and with the application environment;

- the controller which bit size of ADC allows to carry out measurements from analog sensors, without going beyond the admissible error is selected;

- ADC on the controller is implemented;

- the communication device that allows you to transmit the signal to the required and sufficient distance without loss of telemechanical information is selected;

- software that allows visual data reading performance by the operator is developed;

- energy consumption requirements are taken into account, in particular due to battery savings: autonomous power supply of the object, direct current at a voltage of $5 \mathrm{~V}$;

- stable operation in the operating temperature range from -40 to $+60^{\circ} \mathrm{C}$ is provided;

- the results of experimental studies have revealed that in the development of wireless local area networks, to avoid the impact of interference from other equipment on the operation of Wi-Fi networks, it is necessary to use devices that can operate in other frequency bands, for example, for $802.11 \mathrm{~b} / \mathrm{g}$ the $5 \mathrm{GHz}$ band can be used. However, they can have a negative impact on 802.11a and $802.11 \mathrm{n}$ networks.

It can be concluded that it is justified to use the wireless short communication subsystem for the organization of the data transmission channel in the training simulator of the automated control system. The chosen equipment meets the requirements of both functionality and reliability. Thus, the setting $\mathrm{Wi}-\mathrm{Fi}$ in educational institutions requires competent technical analysis and calculation, which will optimize the requirements for the purchase of equipment, its location, ensuring the necessary coverage area to the network, and compliance with health and safety rules and regulations, aimed to prevent the harmful effects of electromagnetic fields on the health of students and staff of the educational institution.

The obtained results should be used for students to master the curriculum in the areas of training specialists in modern power management systems, automated control systems and also for informatization of education, which will improve the quality of graduates training.

The authors express their gratitude to Ternopol radio-technics design bureau «Strila» and their manager Oleksandr Rafaliuk, chief engineer Serhiy Piskun and programmer Serhiy Dudin in particular, for their important contribution into development of simulation model. We are especially thankful to Yurii Staryk, the graduate student of Electric engineering department of Ternopol Ivan Puluj National Technical University for his assistance in developing the information processing module for the wireless local area network.

\section{References}

1. Orobchuk B. Ia. Dilovi ihry $\mathrm{v}$ navchalnomu protsesi $\mathrm{v}$ yakosti instrumenta profesiinoi pidhotovky mahistriv. VI Mizhnarodna naukovo-tekhnichna konferentsiia "Svitlotekhnika y elektroenerhetyka: istoriia, problemy, perspektyvy" (Ternopil - Yaremche, 30 sichnia - 2 liutoho 2018 r.). M-vo osvity i nauky Ukrainy, Tern. natsion. tekhn. un-t im. I. Puliuia [ta in]. Ternopil: TNTU, 2018. P. 95-96. [In Ukraine]. 
Development and research of Wi-Fi network for receiving and transmitting telemechanical information in the training laboratory

2. V. G. Shevchuk, V. V. Levtrinskiy, N. A. Shevchuk Grafo-planovyie kartyi tehnologicheskih protsessov v uchebnyih kursah. Progressivnyie tehnologii obucheniya v vuze: Tezisyi dokladov Mezhdunar. nauchn.metod. konf. Gomel: BelGUT, 2000. P. 144-145 [in Belarus].

3. Orobchuk B. Ia., Piskun S. O., Rafaliuk O. O. Vprovadzhennia system telemekhaniky keruvannia enerhoobiektamy v navchalnomu protsesi. III Vseukrainska naukova-tekhnichna konferentsiia "Teoretychni ta prykladni aspekty radiotekhniky i pryladobuduvannia" (Ternopil, cherven 2017 r.). M-vo osvity i nauky Ukrainy, Tern. natsion. tekhn. un-t im. I. Puliuia [ta in]. Ternopil: TNTU, 2017. P. $224-226$ [in Ukraine].

4. Orobchuk B. Ia., Buniak O. A. Metodyka zastosuvannia systemy keruvannia rezhymamy elektropostachannia u navchalnomu protsesi. Materialy VII mizhnarodnoi naukovo-tekhnichnoi konferentsii "Pidvyshchennia rivnia efektyvnosti enerhospozhyvannia v elektrotekhnichnykh prystroiakh i systemakh" (Lutsk, 23 chervnia 2018 r.). M-vo osvity i nauky Ukrainy, Lutskyi natsion. tekhn. un-t [ta in]. Lutsk: LNTU, 2018. P. 67-71 [in Ukraine].

5. IEEE P802.11s/D1.08. Amendment: Mesh Networking. IEEE, January 2008.

6. Zakon Ukrainy "Pro radiochastotnyi resurs Ukrainy" vid 1 chervnia 2000 roku No. 1770-III.

7. IEEE Std 802.11-2007. Wireless LAN Medium Access Control (MAC) and Physical Layer (PHY) Specifications. IEEE, June 2007.

8. Orobchuk B. Ia. Laboratornyi kompleks dlia pobudovy system telekeruvannia i dyspetcherskoho upravlinnia v elektroenerhetytsi. Materialy KhKh naukovoi konferentsii TNTU im. I. Puliuia (Ternopil, traven 2017 r.). M-vo osvity i nauky Ukrainy, Tern. natsion. tekhn. un-t im. I. Puliuia [ta in]. Ternopil: TNTU, 2017. P. 170-171 [in Ukraine].

9. B. Orobchuk, I. Sysak, S. Babiuk Intellectual system of street lighting control in a city. VI International Conference of Students, PhD Students and Young Scientists "Engineer of XXI Century": Inzynier XXI Wieku Prozektujemy Przyszlosc. Wydawnictwo Naukowe AkademiiTechniczno-Humanistycznej w Bielsku-Bialej, December 2016. P. 825-832.

10. Chesanovsky I., Levhunets D. (2017) Representation of narrow-band radio signals with angular modulation in trunked radio systems using the principal component analysis. Scientific Journal of TNTU (Tern.), vol. 86, no. 2, pp. 117-121 [in English].

11. Trembach B., Kochan R., Trembach R. (2016) Multiplex digital correlator with high priority deployment of one of the acoustic signal receivers. Scientific Journal of TNTU (Tern.), no. 4 (84), pp. $99-104$ [in English].

12. Vishnevskiy V. M., Lyahov A. I., Portnoy S. L., Shahnovich I. L. Shirokopolosnyie besprovodnyie seti peredachi informatsii. M.: Tehnosfera, 2005 [in Russian].

13. B. Orobchuk, I. Sysak, S. Babiuk, T. Rajba, M. Karpinski, A. Klos-Witkowska, R. Szkarczyk, J. Gancarczy Development of simulator automated dispatch control system for implementation in learning process. 2017 9th IEEE International Conference on Intelligent Data Acquisition and Advanced Computing Systems: Technology and Applications (IDAACS). IEEE, Buharest, vol. 1, September 2017. P. 210-214. https://doi.org/10.1109/IDAACS.2017.8095078

14. Automated system of dispatching control (ASDC) "Strila". Technical description and operating manual. Ternopil Design Bureau of Radiocommunication "Strila". [In Ukraine].

15. Orobchuk B. Ia., Staryk Yu. I. Vprovadzhennia tekhnolohichnoi radiomerezhi obminu danymy. Aktualni zadachi suchasnykh tekhnolohii: zb. tez dopovidei mizhnar. nauk.-tekhn. konf. molodykh uchenykh ta studentiv, (Ternopil, 27-28 lystop. 2019.). M-vo osvity i nauky Ukrainy, Tern. natsion. tekhn. un-t im. I. Puliuia [ta in]. Ternopil: TNTU, 2019. T. 3. P. 73-74. [In Ukraine].

16. IEEE Std 802.11, 1999 Edition. Wireless LAN Medium Access Control (MAC) and Physical Layer (PHY) Specifications. IEEE, August 1999.

17. IEEE P802.11s/D1.00. Amendment: Mesh Networking. IEEE, November 2006.

\section{Список використаної літератури}

1. Оробчук Б. Я. Ділові ігри в навчальному процесі в якості інструмента професійної підготовки магістрів. VI Міжнародна науково-технічна конференція «Світлотехніка й електроенергетика: історія, проблеми, перспективи» (Тернопіль - Яремче, 30 січня - 2 лютого 2018 р.). Тернопіль: ТНТУ, 2018. С. 95-96.

2. Шевчук В. Г., Левтринский В. В., Шевчук Н. А. Графо-плановые карты технологических процессов в учебных курсах. Прогрессивные технологии обучения в вузе: Тезисы докладов Междунар. научн.метод. конф. Гомель: БелГУТ, 2000. С. 144-145

3. Оробчук Б. Я., Піскун С. О., Рафалюк О. О. Впровадження систем телемеханіки керування енергооб'єктами в навчальному процесі. III Всеукраїнська наукова-технічна конференція «Теоретичні та прикладні аспекти радіотехніки і приладобудування» (Тернопіль, червень 2017 р.). Тернопіль: THTУ, 2017. C. 224-226. 
4. Оробчук Б. Я., Буняк О. А. Методика застосування системи керування режимами електропостачання у навчальному процесі. Матеріали VII міжнародної науково-технічної конференції «Підвищення рівня ефективності енергоспоживання в електротехнічних пристроях і системах» (Луцьк, 23 червня 2018 р.). Луцьк: ЛНТУ, 2018. С. 67-71.

5. IEEE P802.11s/D1.08. Amendment: Mesh Networking. IEEE, January 2008.

6. Закон України «Про радіочастотний ресурс України» від 1 червня 2000 року № 1770-III.

7. IEEE Std 802.11-2007. Wireless LAN Medium Access Control (MAC) and Physical Layer (PHY) Specifications. IEEE, June 2007.

8. Оробчук Б. Я. Лабораторний комплекс для побудови систем телекерування і диспетчерського управління в електроенергетиці. Матеріали XX наукової конференції ТНТУ ім. І. Пулюя (Тернопіль, травень 2017 р.). Тернопіль: ТНТУ, 2017. С. 170-171.

9. Orobchuk B., Sysak I., Babiuk S. Intellectual system of street lighting control in a city. VI International Conference of Students, PhD Students and Young Scientists «Engineer of XXI Century»: Inzynier XXI Wieku Prozektujemy Przyszlosc. Wydawnictwo Naukowe AkademiiTechniczno-Humanistycznej w Bielsku-Bialej, December 2016, pp. 825-832.

10. Chesanovsky I., Levhunets D. Representation of narrow-band radio signals with angular modulation in trunked radio systems using the principal component analysis. Вісник ТНТУ. 2017. Том 86. № 2. С. 117121.

11. Trembach B., Kochan R., Trembach R. Multiplex digital correlator with high priority deployment of one of the acoustic signal receivers. Вісник ТНТУ. 2016. № 4 (84). С. 99-104.

12. Вишневский В. М., Ляхов А. И., Портной С. Л., Шахнович И. Л. Широкополосные беспроводные сети передачи информации. М.: Техносфера, 2005.

13. Orobchuk B., Sysak I., Babiuk S., Rajba T., Karpinski M., Klos-Witkowska A., Szkarczyk R., Gancarczy J. Development of simulator automated dispatch control system for implementation in learning process. 2017 9th IEEE International Conference on Intelligent Data Acquisition and Advanced Computing Systems: Technology and Applications (IDAACS). IEEE, Buharest, vol. 1, September 2017, pp. 210-214. https://doi.org/10.1109/IDAACS.2017.8095078

14. Автоматизована система диспетчерського керування «Стріла». Технічний опис і інструкція 3 експлуатації. Тернопіль, 2010.

15. Оробчук Б. Я., Старик Ю. І. Впровадження технологічної радіомережі обміну даними. Актуальні задачі сучасних технологій: зб. тез доповідей міжнар. наук.-техн. конф. молодих учених та студентів, (Тернопіль, 27-28 листоп. 2019.). Тернопіль: ТНТУ, 2019. Т. 3. С. 73-74.

16. IEEE Std 802.11, 1999 Edition. Wireless LAN Medium Access Control (MAC) and Physical Layer (PHY) Specifications. IEEE, August 1999.

17. IEEE P802.11s/D1.00. Amendment: Mesh Networking. IEEE, November 2006.

\title{
УДК 621.311.4-519
}

\section{РОЗРОБЛЕННЯ ТА ДОСЛІДЖЕННЯ WI-FI МЕРЕЖІ ДЛЯ ПРИЙМАННЯ Й ПЕРЕДАВАННЯ ТЕЛЕМЕХАНІЧНӦ̈ ІНФОРМАЦІЇ В УМОВАХ НАВЧАЛЬНОЇ ЛАБОРАТОРІЇ}

\author{
Богдан Оробчук; Вадим Коваль
}

\section{Тернопільський наиіональний технічний університет імені Івана Пулюя, Тернопіль, Україна}

\begin{abstract}
Резюме. Важливою складовою професійної підготовки фахівців інженерного рівня, особливо в сучасній електроенергетичній галузі, є застосування в навчальному процесі комп'ютерних систем автоматизації інженерної праці. Це дозволяє наблизити студентів до вирімення реальних практичних інженерних завдань, навчити на практиці формувати необхідні практичні навички, розвивати професійно орієнтовану інтуїиію і впевненість майбутнього фахівця у своїй професійній компетенції та можливості самостійно вирішувати складні інженерно-практичні завдання. В статті розглянуто питання розроблення, дослідження та впровадження бездротових локальних мереж у навчальний процес, зокрема побудови Wi-Fi мережі, проведення дослідження рівня сигналу для передавання даних диспетчерського керування на базі навчального тренажера цією мережею в лабораторії дистанційного
\end{abstract}


Development and research of Wi-Fi network for receiving and transmitting telemechanical information in the training laboratory

управління електроенергетичними об'єктами. Для контрольованого пункту телемеханіки застосовуються провідні системи для зв'язку оператора з різноманітними датчиками та виконавчими механізмами, щз створює певні труднощі й небезпеки для роботи оператора, який знаходиться поблизу пункту телемеханіки. Розглянуто варіант потениійно можливого використання бездротових технологій y навчальному прочесі, який демонструє, як можна убезпечити роботу оператора й скоротити час на обхід усіх датчиків та виконавчих механізмів. розробити підсистему бездротового зв'язку ближнього радіуса дії. Метою даного розроблення та дослідження є підвищення якості обслуговування контрольного пункту телемеханіки за рахунок розроблення для нього програмно-апаратного засобу, щьо дозволяє вирішити завдання автоматизачії та безпеки. Об'єктом дослідження вибрано навчальний диспетчерський тренажер управління електроенергетичними об'єктами, а предметом дослідження $\epsilon$ процес збирання та передавання інформації з контрольного пункту телемеханіки.

Ключові слова: телекомунікачійні технології, Wi-Fi, локальна бездротова мережа, навчальний процес, телемеханіка, електроенергетика. 